\title{
A narratological analysis of Mark 12: 1-12: \\ The plot of the Gospel of Mark in a nutshell
}

\author{
E van Eck \\ $\&$ \\ AG van Aarde \\ University of Pretoria
}

\begin{abstract}
A narratological analysis of Mark 12: 1-12: The plot of the Gospel of Mark in a nutshell

The purpose of this article is an attempt to read Mark 12: 1-12 in terms of the plot of the Gospel. Firstly a brief survey is given of the development of the term plot from Aristotle to the present, thereafter an own methodological point of departure concerning plot is formulated in order to study the plot of Mark. The conclusions made from this are used to indicate how Mark 12: 1-12 fits into the plot of the Gospel and what functional role it plays in the development of the plot. The conclusion reached is that Mark 12: 1-12 contains the plot of Mark in a nutshell.
\end{abstract}

\section{INTRODUCTION}

The purpose of this article is to read Mark 12: 1.12 in terms of the plot of the Gospel of Mark. This is done in Section 2 through investigation of the literary theoretical development of the study of plot from Aristotle to the present day. On the grounds of the study a private methodological point of departure will be formulated in terms of which the plot of the Gospel of Mark will be studied in Section 3. In Section 4 attention will be given in terms of the conclusion arrived at in the previous section, to what functional role Mark 12: 1-12 plays in the plot of Mark. The conclusion arrived at is that the selected pericope not only vigorously drives

- Submitted and accepted as part of the requirement for the MDiv degree, Faculty of Theology (Section A), University of Pretoria, under guidance of Prof Dr AG van Aarde. 
forward the plot of Mark, but is also a parable of what the world has been told and the plot of the Gospel of Mark summarized in a nutshell. In Section 5 a few closing remarks suffice.

\section{THE TERM 'PLOT}

\subsection{A survey of the development of the term 'plot'}

A study of the development of the term 'plot' can not begin but with the contribution made by Aristotle. Stevens (in Dipple 1970: 44) defines Aristotle's contribution in this regard as follows: 'Aristotle is a skeleton. As regards plot

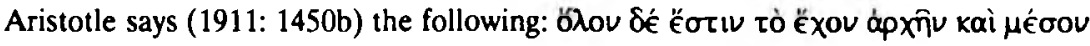
kai $\tau \epsilon \lambda \epsilon u \tau \tilde{\nu}$. According to Aristotle any well constructed plot consists of three main elements, namely a beginning, a middle and an end. The connection between these three elements can be expressed as follows (cf Van Aarde [1989]. An elementary, well constructed plot usually consists of the linear sequence, a beginning which leads to the middle and the end. The beginning of the plot introduces the action and creates expectation; in the middle the action is developed from the beginning and that presupposes an unravelling (denouement) which is developed in the ending (my italics and translation).

The term with which Aristotle works, is therefore causality (see also Kenney 1966: 14-19 in this regard).

A number of contemporary literary theorists support Aristotle that the term causality is the term with which plot can be defined. Scholes and Kellogg (1966: 12, 207) regard plot as 'an outline of events, an articulation of the skeleton of narrative ... the dynamic, sequential elements in the narrative'; Ricoeur (1980: 167) as 'the connection function between an event or events in the story'; Muir (1968: 177) as 'the principle which knits together a story's chain of events'. Kenney (1966: 14), Vorster (1980: 126) and Senekal (1985: 83) also regard causality as the term with which the concept plot can be expressed.

Dipple (1970: 3, 67) and Egan (1978: 455) however, are of the opinion that Aristotle was responsible therefore that plot is currently regarded as a static term. According to them the fact is evident that so many contemporary literary theorists, in reaction to Aristotle, regard plot from other angles. To my mind, there are four trends in reaction to Aristotle.

The first trend emphasized the term characterization. According to Forster (1927: $121-134 ; 1961: 219-222)$ causality does play a role in the plot of a narrative, 
but it is the characters (Forster 1961: 220) that create, through their actions, complexity and suspense in a narrative, and also make possible the solution of the plot (see also Matera 1987: 235; Culpepper 1983: 80 in which they incorrectly interpret Forster in this regard). Forster also has strong support form Friedman in this respect. According to Friedman (1967: 154-156) due attention should be given to the development/change which the principal character's thoughts, actions or attitude undergo in a narrative in order to determine the plot. Like Forster, characterization is also for him the aspect which constitutes the plot of a narrative.

The second trend emphasizes time or final causality of plot in a narrative. Crane (1967: 144) says the following about plot: 'the plot ... is ... not simply a means - a 'framework' or 'mere mechanism' - but rather the final end which everything in the work ... must be made, directly or indirectly, to serve'. Booth (1961: 126) again, sees plot as the 'causal completion' of a narrative. According to Kermode (1966: 167) plot is 'an organization that humanizes time by giving it form and final completion', and Brooks as 'goal-orientated and forward moving'. Ford, in turn, regards the end of the plot as 'a sense of inevitability'.

The third trend emphasized the emotional effect which the plot has on the reader. Exponents of this school of thought are the following: Egan (1978: 470) who sees plot as that which leads to 'a determinate affective response'; Dipple (1970: 67) who regards plot as 'a word which establishes a liaison between reader and literary text', while Abrams (1971: 127) regards plot as 'the structure of its actions, as these are ordered and rendered toward achieving particular emotional and artistic effects'.

The last trend allows the study of plot to rise in the traditional distinction between histoire and recit (cf Genette 1980: 33-85) or story time and plotted time (cf Petersen 1980: 151-166) or, as it stand known in the Russian Formalism, the difference between fabula and suzjet. According to Chatman (1978: 43) plotted time is nothing more than the plot of a narrative and for Tomahevsky (1965: 67) plot is '... how the reader learns of the action (i e the time of the narrative text $-E \vee E$ ). Also Bowen (1960: 330) and Scholes (1974: 80) express the same opinion in this regard.

\subsection{Summary and methodological justification}

On the strength of the abovementioned review it is clear that plot can organize the incidents in a narrative in one of five ways, namely by means of causality, as a result of the ending or final causality, with the aid of characterization or by means of the difference between story time and plotted time or as a result of the effect that the plot has on the reader of the narrative. A critical analysis of the five approaches gives rise to the following: in my estimation a distinction can not really be indicated 
between the first two approaches. The reason for this is the fact that the second approach gives the impression that Aristotle did not consider the ending of a narrative, although he did regard plot as consisting of beginning, middle and ending (cf also Goodman 1954: 14; Van Aarde [1989] in this respect). These two approaches can therefore be grouped under one heading.

The above-mentioned critical analysis therefore also gives rise to the question of a responsible methodology. Should only one of the abovementioned opinions be accepted, or would a combination of two or more be methodologically acceptable and responsible? Matera (1987a: 239-240), in a study of the plot of Matthew, is of the opinion that a study of plot can be fully done if only time and causality are taken into account. According to him plot consists of the arrangement of the events in a narrative by means of time and causality. All events in a narrative are, however, not equally important. Matera (1987a: 237) formulates his last above-mentioned view as follows: 'One must also recognize that not all events are of equal importance. Some are more important and more necessary to the plot than others'. To distinguish between events which are less or more important to the plot, he makes use of Chatman's (1978: 45-53) terms, kernels and satellites.

A 'kernel' is 'a major event' (Matera 1987a: 237) because it helps the plot along vigorously, usually initiates the intrigue ('crux') of the narrative, can not be left out without interrupting the logical establishment of the plot and finally because one kernel requires another in support of the culmination of events which initiated the first kernel (cf Chatman 1978: 53-56). In this way a sequence of actions in a narrative is created. This sequence of actions 'serves as an outline of the plot' (Matera 1987a: 237). On the other hand a satellite (Rimmon-Kenan 1983: 16 prefer the term catalyst) is an event that can be left out without detrimentally affecting the logical establishment of the plot (Chatman 1978: 55), or, as Matera (1987a: 238) formulates it, 'not cruxes in the narrative'. It can be agreed with Matera (and also with Chatman) that this approach can be used profitably to distinguish between events which are important (and essential) for the development of the plot, and which can be left out so that which is basic to the plot of a narrative, can be identified. And yet I am of the opinion that this method is unsatisfactory because although time and causality receive the required attention, no study of characterization and the role of the reader in regard to the development of the plot is included; two aspects without which no study of a plot can be fully done.

I am of the opinion that the method of Van Aarde [1989] is most useful. According to Van Aarde the essence of the study of plot lies in the unravelling of the following interrelations which are found in a narrative: the interrelation between 1) narrative discourse and real reader, 2) the real reader and the implied writer, 3) 
the implied writer and the implied reader/listener, 4) the implied writer and the narrator, 5) the narrator and the narratee, 6) the narrator and the narrated characters, and 7) the narrated characters in reciprocal dealings who move within a specific structure of time and space. Interrelations 3-7 constitute the plot, according to Van Aarde.

Van Aarde (1989:5) is therefore of the opinion that an in-depth study of plot implies looking at the narrated characters, time, space, the role of the reader in a narrative and the causality that exists between these narrative elements. Van Aarde's method therefore makes provision for the conclusion of all four approaches that we identified above, as well as the study of space. Particularly on the grounds of the completeness of this method will it be applied below. For the sake of the magnitude of the article under question, the question of space will not be considered (for a description of the study of space in the Gospel of Mark, see Van Eck 1986: 339 349; 1988: 139-163).

A final methodological remark: when it is stated that the beginning, middle and ending of the Gospel is to be treated, these various sections should be clearly defined. In this respect we shall retain Vorster's (1980: 123) division, namely as introduction Mark 1: 1-15, as body Mark 1: 16-14: 42 and as ending Mark 14: 43-16: 8 (for other divisions see Matera 1988: 4-5; Keck 1966: 359-360).

\section{THE PLOT OF THE GOSPEL OF MARK}

\subsection{Plot in terms of narrated time}

The study of plotted time can, amongst other things, develop into an enquiry into the underlying principle that 1) questions the chronology and the causality between the various episodes, 2) is situated in the 'divergence' of the linear course of time and 3) allows the various lines of action to function together in a set context of 'meaning' (Van Aarde [1989]. For the purposes of this article we shall concentrate on the latter. Tannehill (1980: 60-62) formulates the possibility of two or more lines of action in a narrative, as applied to the Gospel of Mark, as follows:

The Gospel of Mark is the story of the commission that Jesus received of God and what Jesus has done (and will do) to fulfill his commission (i e to say the Jesus mission - E v E).... Although Jesus' commission is central in Mark, many other commissions and tasks are suggested .. In 1: 16-20 Jesus calls four fishermen to follow him. This establishes the disciples' commission and start a sequence of events ... (i e to say the 
disciples's commission - E $\vee$ E).

According to Tannehill we can therefore indicate two lines of action in the Gospel, which Van Aarde (1982: 128) content-wise formulates as follows: 'the sequential level of the Jesus-mission and the sequential level of the disciple-mission'.

The above view as expressed by Tannehill is largely founded upon the Frenchstructuralistic views of Greimas (see Pelser [1983]: 35-57). Van Aarde (1986: 62-63) connects this with the narratological views of Eberhard Lämmert. To Lämmert (1972: 40-44) it is clear that a narrative can contain more than one line of action (Handlungsstrang). If such be the case, then one line of action always functions dominantly (ubergeordnete Handlung) with regard to another/other line(s) of action (eingelagerten Handlungsträngen) in a narrative. Usually there exists a definite context of meaning (Verknüpfungsprinzip) between these different narrative lines in a narrative. According to Van Aarde this context of meaning can be parallelistic, anticipatory, analog, symbolic, allegoric or contrary by nature. At the end of Section 3.1.1 and 3.1.2 it will become evident that the bond between the mission of Jesus and the mission of the disciples is analogic and/or symbolic by nature (Van Aarde 1986: 56).

\subsubsection{The narrative line of the mission of Jesus}

The narrative line of the mission of Jesus starts in Mark 1: 9 where Jesus appears on the scene for the first time. After he was baptized by John, the Spirit descends upon him and he is addressed by God as his Son. Subsequently the Spirit immediately takes him to the desert where Jesus is tempted by Satan. After the temptation Jesus returns to Galilee (Mark 1: 14), after which he immediately announces the contents of his Gospel and begins with his mission (cf also Tannehill 1980: 61 in this regard).

In the middle, building is continued on the particulars provided in the introduction. Mark 1: 16-3: 6 is mainly concerned with the fact that the other important characters in the narrative are introduced and also that the authority that Jesus received at his baptism, is made known. As far as these characters are concerned, the following can be stated: in Mark 1: 16-20 Jesus calls his disciples, for the first time he has to do with an impure spirit (Mark 1: 23) and the masses (Mark 1: 27), and in Mark 2: 6 with the scribes. Jesus's authority becomes manifest when he frees someone of this impure spirit (Mark 1: 23), drives out demons (Mark 1: 40-41), heals the sick (Mark 1: 29-31; 1: 40-45; 2: 1-12; 3: 1-6), forgives sins (Mark 2: 10, 17) and also proclaims that he reigns over the Sabbath (Mark 2: 27-29; 3: 4-5). These actions of Jesus lead to his growing popularity with the masses (Mark $1: 28 ; 2: 12$ ). Jesus is therefore presented as the victor, even though the subsequent resistance 
offered by the Pharisees is suggested in Mark 2: 6 .

From Mark 3: 7-8: 26 attention is focussed on the development of the relationships especially between Jesus and the disciples and the Pharisees (Tannehill 1980: 86). Of Jesus's relationship with the disciples the following is evident: in Mark 3: 1319 Jesus formally appoints the Twelve and in Mark 4: 1-34 Jesus tells the parable of the sower which he later explained only to the disciples. They learn that the thidden meanings' (mystery) of the Kingdom is bestowed upon them (Mark 4: 11-12), that they must sow the Word like Jesus (Mark 4:13-20) and that they will be measured with the selfsame measure should they fail to preach the Word as they know they should (Mark 4: 24-25). Should they, however, preach the Word as they were taught, the Kingdom will grow (Mark 1: 28; 2: 12) and even become very large (Mark 4: 3032).

Subsequently we come across the three boat narratives (Mark 4: 35-41; 6: 45-52; 8: 14-21). Here Jesus realizes more and more that the disciples have paradoxically no faith because they don't understand who he is and what he had taught them up to that point in time. In Mark 6: 7-12 Jesus sends the disciples to go out and do what he had done till then, which they carry out successfully. Jesus also gives them two opportunities to serve when he multiplied the bread for the masses. In this way they could show that they understood who Jesus is and that they knew what they had to do (Mark 6: 35-44; 8: 1-10). In both cases, however, they fail, because they do not understand who Jesus really is. After this Jesus works more miracles and he heals people to show the disciples who he is, but the disciples fail repeatedly to understand who Jesus is.

The study of the relationship between Jesus and the Jewish leaders in this section (Mark 3: 7-8: 26) produces the following: after the Pharisees and the scribes decide in Mark 2: 6 that Jesus is not permitted to forgive sins, we only meet them again in Mark 3: 1-13 where they question Jesus's authority to disobey the traditional practices of their forefathers. This leads to their asking for a miracle from Jesus in Mark 8: 11-13 as proof that he is from God. The conflict between Jesus and the Jewish leaders is therefore clearly increasing, even though Jesus repeatedly succeeds in getting the better of them.

Up to Mark 8: 27 there is therefore shown in a rising gradient that Jesus, the Son of God, is the victor. In Mark 8: 27-29 there is a turning-point in this success story (Vorster 1980: 127-128). When Peter proclaims Jesus as the Christ, Jesus immediately foretells in three incidents (Mark $8: 31 ; 9: 31 ; 10: 32-34$ ) of his suffering and death, and in so doing clearly spells out who the Christ really is. These three announcements are in each instance followed by a lesson to the disciples about what following really means (Mark $8: 33 ; 9: 32 ; 10: 33-34$ ), while it becomes increasingly 
apparent that they do not understand what it means to follow Jesus the way he wants to. Jesus also announces on two occasions that one of the disciples will betray him (Mark 14: 10-11, 17-21).

Against this background of this lack of understanding of the disciples, we also find in the section Mark 8: 27-14: 42 a growing conflict between Jesus and the Jewish leaders. After Jesus arrived in Jerusalem, he purges the temple (Mark 11: 15 19) which once again raises the question of his authority (Mark 11: 27-33). On the grounds of further conflict (Mark 12: 13-17, 18-27; 12: 28-34) the Jewish leaders decide to kill Jesus (Mark 14: 1-2). This escalating conflict which had already started in Mark 2: 6, has therefore to do with the question of Jesus's authority to forgive sins and in so doing disobeying the traditional practices and purging the temple.

In the ending the threads of the middle follow through. Jesus's announcement of his suffering are fulfilled. He is the Son of God, but the Son who must suffer and die. His disciples finally forsake him (Mark 14: 50). His antagonists take him into custody (Mark 14: 43-51). He appears before the scribes and the Jewish Council (Mark 15: 21-32), dies (Mark 5: 33-41) and is buried (Mark 15: 42-47). In Mark 16 Jesus rises from the dead, an aspect we shall treat in Section 3.3.2.

The narrated line of the mission of Jesus can therefore be summarized as follows: Jesus, as the Son of God, in keeping with the will of God, had to suffer. There is victory as a result of his death because it leads to the true life.

\subsubsection{The narrative line of the mission of the disciples.}

The line of narration of the mission of the disciples starts in Mark 1: 16-20. Even though the disciples are not aware of Jesus's birth, the fact that he is the Son of God, what the essence of his preaching is, they follow him without hesitation (Rhoads and Michie 1982: 89). Here the disciples are portrayed in a most positive manner, also when they react without hesitation when Jesus calls them together on the mountain (Mark 3: 13) and when Jesus sends them forth in Mark 6: 7 and they succeed in their mission (Rhoads and Michie 1982: 90).

A negative image of the disciples is, however, created in the three boat episodes (Mark 4: 35-41; 6: 45-52; 8: 14-21; cf Tannehill 1980: 70). Also when Jesus gives them the opportunity to assist him in feeding the masses (Mark 6: 35-44; 8: 1-10), they stand disconsolate and don't know what to do (for a good exposition of the structure of Mark 14: 1-8: 26, see also Petersen 1980: 191-203).

When Peter professes Jesus as the Christ in Mark 8: 29 it would appear that he understands who Jesus is. However, when Jesus for the first time prophetizes his death immediately afterwards (also after the second and third prophecy of his suffering) it becomes clear that Peter, as well as the other disciples, do not 
understand who Jesus is (see also Tannehill 1980: 64, 68-69; 1983: 400-401, 396 405). Also in the conversations between the disciples themselves on the way to Jerusalem, their misunderstanding becomes more apparent. Instead of being the least and disavowing themselves, the argue who is the most important (Mark 9: 3337) and who will sit where alongside Jesus (Mark 10: 35-45) when Jesus becomes King (Rhoads 1983: 12).

At the ending of the Gospel the threatening conflict between Jesus and his disciples reaches a climax. After Jesus is taken captive in Gethsemane (Mark 14: 32 41), the disciples forsake him in Mark 14: 50, and Peter also renounces him (Mark 14: 66-73). Kingsbury (1981: 52) expresses this line of narration of the mission of the disciples as follows:

The root problem is as consistent lack of comprehension on their (the disciples' - E v E) part .... Indeed, they resist the cardinal truth Jesus would impress upon them, namely, that the way of the disciples is the way of suffering.

The analogic connection between the lines of narration of the mission of Jesus and that of the disciples, Van Aarde [1989] expresses correctly to my way of thinking: the preaching of the Kingdom of God is inseparably bound to the call to follow the paths of Jesus and that it is following in spite of suffering. As Jesus proclaimed, so must the disciples proclaim, even though if they have to suffer and die.

\section{Plot in terms of the narrated characters}

According to Van Aarde (1983: 66-68; [1989] characters in a narrative can have five functions in the action. The protagonist in the Gospel of Mark is the principal character (i e to say, Jesus in the Gospels); the object are the persons at which the values of the protagonist are aimed (i e to say, the followers of Jesus; see also Rhoads \& Michie 1982: 6 in this regard); the antagonists are those whose efforts are aimed at the failure of the mission of the protagonist (i e the Jewish leaders); the helpers are the characters who attempt to help the protagonist in his mission (i e the Twelve Disciples). The function of the arbitrator is not apparent in the Gospels, with the possible exception of the Holy Spirit (cf Van Aarde 1989: 67). The functional role of the arbitrator is usually in the solving of a conflict between two opposing characters through a third party who gets the opponents to agree or to accept the will of the third party (cf Vandermoere 1976: 30). Because of the length of this article, but also as attention was given to the protagonist and the helpers in former sections, attentionin this section will only be given to the antagonists in the Gospel. 
Like the disciples, the Jewish leaders did not know much about Jesus. From Mark 2: 6 to 3: 6 Jesus does a number of things: he forgives sins, he sups with sinners and publicans, he fails to fast as was the practice and he works on the Sabbath, which result in the Pharisees plotting with the Herodians to kill him (Mark 3: 6).

In the section from Mark 7: 1 to $14: 42$ the growing conflict between Jesus and the Pharisees develops. After Jesus calls them hypocritical, they start testing Jesus by setting him all manner of questions and also ask for a sign from heaven which will indicate with what authority Jesus performed all these acts. When Jesus purifies the temple, the headquarters of the Jewish faith, in Mark 11: 15-19, the Pharisees and the head priests devise for a second time a plan to kill Jesus (Mark 11: 18). After Jesus told the parable of the farmers and the vineyards (Mark 12: 1-12), and the Pharisees realize that Jesus is alluding to them, they plan for a third time to kill Jesus (Mark 12: 12), a plan which is repeated in Mark 14: 1-2. When Judas offers to betray Jesus in Mark 14: 10-11, the plan of the Pharisees and the head priests to kill Jesus starts taking shape, while Jesus himself begins prophesying to his disciples that he is to suffer and die.

In the ending of the Gospel the death of Jesus becomes a reality. The Jewish Council find Jesus guilty when he admits that he is the Son of God, the Christ. On the strength of this verdict Jesus is handed over to be executed and he dies on the cross.

The plan of the Pharisees, the head priests and the Herodians therefore succeeds. The irony of the result of the plan of the Jewish leaders is formulated as follows by Rhoads (1983: 6): 'The authorities, who believe they are vindicated by Jesus' death, are really blindly carrying out a divine plan which ultimately seals their own destruction'. The Jewish leaders, in fact, lost that which they wished to protect, namely their 'lives' (cf Mk 8: 34-38).

\subsection{Plot in terms of the implied reader}

Rhoads and Michie (1982: 137) define the implied reader in a narrative as follows:

The implied reader is an extension of the narrative, a reader that the author creates (by implication) in telling the story. ... (a) reader with the ideal responses implied or suggested by the narrative ...'

Booth (1961: 71-72) defines this reader as the 'second self of the implied author, that is to say a reader who reads a narrative precisely as the implied author meant it to be read. The (implied) reader thus functions, according to Booth (1961: 73) as a 
'bundle of norms and values'.

Although the study of the implied reader consists of a variety of facets, we shall only consider two issues, namely the understanding of the title Son of God by the reader, and the reader's understanding of the end of the plot in the Gospel.

\subsubsection{The implied reader and the title Son of God}

The study of the title Son of God in the Gospel of Mark has nearly become synonymous with the theory of Wrede (1901) about the so-called messianic secret in the Gospel of Mark. At a time when the Gospel was regarded as a true historical rendition of the life of Jesus, Wrede attempted to show that the Gospel of Mark contains a theological structure of a particular nature, viz a construction built on the Messiahship of Jesus. According to Wrede, Jesus tried to keep it a secret that he was the Messiah. According to him, Jesus's intention in the Gospel comes to the fore in the motif of secrecy (Mark 1: 23-25, 34; 3: 11-12), in the inability of the disciples to understand Jesus (Mark 4: 13, 40-41; 6: 50-52; 7: 17; 8: 16-21; 9: 6,10) and in the socalled parable theory (see Gnilka 1978: 170-172 for an explanation of this theory) in Mark 4: 10-12. This theory of Wrede was developed and refined, particularly by Luz (1965: 9-30) and Raisanen (1976).

On the one hand, as a reaction to the above theory of Wrede, but on the other hand, also as a result of the greater emphasis laid on the suffering and death of Jesus, the study of the title Son of God is also guided along channels other than those of Wrede and his followers. This group (Weeden 1968: 145-158; 1971: 55; Martin 1972: 140-205; Perrin 1974: 161), although each gives his own accent to the issue, is of the opinion that in the congregation of Mark there was a false Christology in circulation which Jesus saw as Өeî́ ànip who performs miracles. In order to combat this false Christology, Mark offers a Christology which strongly emphasizes the suffering and death of Jesus so as to indicate that Jesus was not a God-man.

As opposed to the above-mentioned two approaches, which both have an historic flavour, there is, however, according to Matera (1987b: 36) a more productive method to examine the title Son of God in the Gospel of Mark, namely 'that which reads Mark's Gospel as a narrative'. Therefore a narratological reading of the Gospel in terms of the title Son of God, provides, in my opinion, the following:

In the introduction to the Gospel (Mark 1: 1-5) the reader receives the following information which none of the other characters in the Gospel have any knowledge of (see also Matera 1988: 6; Rhoads \& Michie 1982: 38): Jesus is the Son of God, he is baptized (on which occasion God addresses him as his Son); he is 
spirited away to the desert where he conquers Satan and when he returns from the desert, he announces the content of his preaching.

On the grounds of this information which only the reader receives, Matera (1988: 3-4) is of the opinion that the introduction is not only the key to the plot of Mark, but is also a good rendering of the complete plot of Mark. As the role of the disciples and Jesus's opponents does not appear in the introduction, and is important, to my way of thinking, for the development and understanding of the plot of Mark, I am not prepared to agree with Matera. In my opinion there can rather be agreement on this matter with Rhoads \& Michie (1982: 104-105) when they typify the function of the introduction of the Gospel as follows:

The narrator also ... reveals Jesus to the reader, primarily by means of the literary motif of secrecy. The narrator ... reveals Jesus to the reader as: 'anointed one' and 'Son of God', but these epithets do not tell what task Jesus is anointed for or what it means that he is God's son. These meanings unfold in the narrative as Jesus struggles to fulfill his destiny and as other characters struggle to understand Jesus.

The introduction therefore functions, in my opinion, to bring the reader to clearly understand who and what this Son of God really is. The reader succeeds in doing this by, while reading the Gospel, complete the term Son of God.

In the section from Mark 1: 16-8: 27 the reader completes the content of the title of Jesus as follows: Jesus exorcizes demons, teaches with authority, heals people and reforms certain Jewish practices. Jesus also appoints his followers who sometimes give the impression that they know who Jesus is, and sometimes not. The Jewish leaders on the other hand, want to oppose Jesus in what he does, a conflict which becomes increasingly fierce. However, when Jesus in Mark 1: 25 and 1: 43 tells the leper not to tell that Jesus had healed him, and in Mark 3:12 forbids the demons (who had addressed him as the Son of God) to tell who he is, the reader does not understand this (cf also Rhoads \& Michie motif above).

When Peter confesses in Mark 8: 29, the reader believes that Peter understands who Jesus is. Jesus' answer to Peter's confession is, however, for the disciples as well as the reader, a surprise, as it provides new information to both (Tannehill 1980: 73). The reader must now reconsider his conception of Jesus. The Son of God is not only the victor, but also the one who is to suffer and die.

The pericope which deals with the glorification on the mount (Mark 9: 2-13) is a turning-point in the Gospel as far as the reader is concerned. In Mark 9: 7 Jesus, for the second time, is addressed as the Son of God, but this time the words are directed 
at the disciples when God tells them: 'Listen to him'. When Jesus descends from the mountain, he charges the disciples not to disclose to anyone 'until the Son of Man had risen from the dead'. For the reader the reason for the secrecy which Jesus demanded up to that point from anyone who addressed him as Son of God, is now clear. Jesus does not want anyone to address him as the Son of God without appreciating that the titled is coupled with his suffering. The reader comes to this realization particularly as a result of the fact that Jesus so recently had announced his suffering in Mark 8: 31 (cf also Matera 1988: 12 in this regard). The words: 'Listen to him' is the key to the question why the disciples may not yet say that Jesus is the Son of God. As they would not yet listen to what Jesus was attempting to tell them, and therefore not understanding that Jesus is the Son of God who must suffer and die, they must listen, and then they will also understand everything. If one, therefore addresses Jesus as the Son of God, Jesus wishes that person to know: He is the Son because of his suffering. This is the conclusion to which the reader comes when the Roman in Mark 15: 39, the first human character in the narrative to do so, addresses Jesus as such. He does this while he witnesses Jesus's suffering and death.

Although Matera will not entirely agree with the interpretation of the understanding of the title Son of God in the Gospel of Mark (cf Matera 1987b: 3637), his following remark, which concerns the value of a narratological reading for the understanding of the title in question, is very relevant:

Such a method (that is to say a narratological reading of the text - Ev E) allows the text to speak for itself and is not dependent upon external hypotheses of alleged heresies. Such a reading suggests to me that Mark's preferred designation for Jesus is Son of God and that the so-called messianic secret revolves around this title ... the evangelist shows his readers that it is not possible to understand who Jesus is apart from his death on the cross. No heresy need be posited within the Marcan community beyond the 'heresy' which afflicts Christians of every age-flight from the cross (Matera 1987b: 37).

\subsubsection{The implied reader and the end of the plot}

When the reader reads the last chapter of the Gospel, he is already acquainted with the two narrative lines in particular, and the role of the Jewish leaders in the plot of the Gospel. He therefore knows that Jesus has completed his mission successfully, particularly with the aid of the Jewish leaders, and it would appear that the disciples had forsaken Jesus. Mark 16: 7-8 brings the reader to a new turning-point in the Gospel, namely that of fear. Donahue (1982: 81-83 formulates this fear as follows: 
This motif (i e the one of fear - E v E) which throughout the Gospel establishes rapport with the reader and which dictates how the reader should respond to Jesus, now becomes a symbolic reaction to the whole Gospel. Mark's reader is left, not with the assurance of resurrection vision, but simply with numinous fear in the presence of divine promise.

Also Rhoads \& Michie (1982: 140) hold the same view in this respect as Donahue when they remark on this sudden turningpoint in Mark 16: 7-8 (see Tannehill 1980: 153):

... the reader expects the grave to be empty but does not expect the surprising flight and the silence of the women. This abrupt ending, which aborts the hope that someone will proclaim the good news, cries out for the reader to provide the resolution to the story. The reader is ... now left with a decision, whether to flee in silence like the women or to proclaim boldly in spite of fear and death.

So the text ends, but not the role of the reader. The reader must re-survey to see if he is able to understand this open ending of the Gospel.

According to Tannehill (1983: 394) Mark 13 is 'the clue to the post-Eater situation as the author sees it' and is also strongly supported by Petersen (1983: 157) in this respect. Although Mark 13 comes before the tale of suffering in the Gospel, the reader comes to the following conclusion when he reconsiders this chapter: the disciples will be handed over and beaten by the authorities; they will be put on trial by governors and kings for the sake of Jesus's name; the Gospel will be preached to the entire world; they will be hated, all because they will follow Jesus and preach the Gospel as they should. They will also defend Jesus against the false christs and Jesus will return on the clouds (cf Mark 14: 68). The disciples therefore follow Jesus in the post-Easter period (see also Vorster 1987b: 203-224 for another interpretation of Mark 13).

The reader however also remembers other actions in the Gospel, except the one in Mark 13, which likewise indicate that the disciples will follow Jesus. In Mark 10: 39 Jesus says to John and James that they will also drink from the cup from which he has drunk. They will also suffer as he is suffering. The last part that the reader also remembers is that of the officer's confession in Mark 15: 39. As one person really understands who Jesus really is, the reader accepts that there will also be others who 
will preach his message (cf also Rhoads \& Michie 1982: 114; Matera 1988: 14).

I am of the opinion that there should be agreement with the conclusion arrived at by Rhoads \& Michie (1982: 98): 'All these prophecies (i e those mentioned above - E v E) affirm that the disciples will continue to follow Jesus and will suffer in the course of proclaiming his good news of the rule of God'. The narrator therefore leads the reader in judgement of the disciples, but not in rejecting them.

The above interpretation of the end of the Gospel has, in my opinion, two results. Firstly the reader realizes that the pre-Easter line of narration of Jesus' mission is pursued on the post-Easter level by the mission of the disciples. Secondly, a continuation between the post-Easter situation of the disciples and that of the reader is also suggested. The reader realises that he must also now follow as the disciples followed Jesus, whatever the nature of the situation.

\subsection{Resume}

As a result of the above approach to the plot of the Gospel of Mark, we are able to formulate the plot of the Gospel as follows: Jesus Christ as Son of God, in accordance with the will of God, but with the aid of the Jewish leaders, had to suffer. Jesus, however, announces at his resurrection that true life follows suffering which culminated at the cross.

Having explained the plot of the Gospel of Mark, we shall now proceed to discuss Mark 12: 1-12 in terms of the plot of the Gospel.

\section{MARK 12: 1-12 IN TERMS OF THE PLOT OF MARK}

Mark 12: 1-12, together with Mark 4 and Mark 13, are the only three longer speeches by Jesus in the Gospel. Furthermore it is, as with Mark 4, delivered in the form of a parable. Rhoads (1983: 14) formulates the functions of the parables (and citations from the Old Testament that appear in Mark) as follows:

A narrative analysis of all the parables in Mark suggests that they are allegories which refer to action and people in the past, present and/or future of the story world. Jesus tells parables either to obscure or clarify the meaning of those actions and happenings for other characters (my italics).

Vorster (1985: 63) also expresses the same point of view as Rhoads in this regard when he expresses the function of the parable in the Gospel as follows: 'Because 
they are used in a context, they refer within that context .... Embedded parables ... have referents in the narrative world of the text into which they are inserted'.

The two points of view above of Rhoads and Vorster also correspond with the well-known distinction between tenors and vehicles in the theory of comparative construction (cf Gräbe 1986: 279-280). In a comparison like the word of God is (like) the seed', the word of God is a tenor and the seed, a vehicle. The tenor is really what the issue is all about, while the vehicle functions in order to specify the tenor metaphorically. The importance of this distinction is that a parable usually only names the tenors, and that the reader himself must determine the vehicles which describe these tenors metaphorically. It simply means that the reader must try to determine to what vehicles (inside and outside the narrative) the tenors refer. In terms of the parable of the farmers and the vineyard in Mark 12: 1-12, the vehicles (in the remainder of the narrative) to which the tenors (which appear in Mark 12: 112) refer, will have to be sought.

To read Mark 12 in terms of the plot of the Gospel, we therefore take as a starting point, that the parable, as a metaphor (or a number of tenors), refer to incidents and persons in the world of the narrative text (i e to say, vehicles), in order to feed certain information to certain characters.

Before we proceed to show everything to which the parable in Mark 12 refers, it is necessary to indicate where it figures in the plot of Mark. This is done by determining the functional position of the parable in the plot in terms of the disciples' and the Jewish leaders' understanding of who Jesus is just before the parable is told, as well as the disciples' and Jewish leaders' understanding of who Jesus is just after the parable has been told.

What the disciples' understanding of who Jesus is, just prior to relating the parable, the following is evident: subsequent to their initial positive actions in answer to Jesus's instructions, it becomes systematically evident that they do not understand who Jesus is. After Peter's confession they hear three times that Jesus must suffer and die. During Jesus's glorification on the mount, they hear that he is the Son of God and that they should listen to him. When Jesus therefore tells the parable in Mark 12, they still do not understand who Jesus is.

The Jewish leaders, on the other hand, in turn, met Jesus in Galilee where he appeared and acted in a way which they could not condone (cf particularly Mark 1: 16-8: 26). They regard him as a threat to that which they represent and cherish and already they had planned on two occasions to kill him. In particular, they wish to know with what authority he acted in the way he did, and have even asked for a sign from heaven from him to prove himself. Jesus also entered the temple and purified it. They therefore also do not know who Jesus is before the telling of the parable. 
This escalating conflict between Jesus and the Jewish leaders leads to the scribes, the head priests and the heads of families again questioning him as to where his authority comes from (Mark 11: 28). Jesus then decides to tell them the parable of the farmers and the vineyard in answer to the question of where his authority comes from (Mk 11: 33).

In terms of the viewpoints offered by Rhoads and Vorster (and Gräbe's interpretation of comparative theories above), and also our own point of view, the elements (tenors) in the parable mean and refer, in my opinion, as follows:

A man (God) planted a vineyard (Israel) and leased it to farmers (the Jewish leaders). Kingsbury (1986: 645) is of the opinion that the 'vineyard' can also refer to the 'prerogative that Israel has enjoyed as God's chosen people'. After this God first sent three slaves individually and then many more. These slaves represent the prophets who God sent 'to reap the fruit from the vineyard, but the slaves were all mistreated or killed' (Rhoads and Michie 1982: 74). Some of the 'slaves' to whom Jesus refers here are probably Isaiah (Mark 1:2), Malachi (Mark 1:3) and John the Baptist (Mark 1: 4). Rhoads and Michie (1982: 119-122) make the following point regarding God's portion of the produce of the vineyard: The Jewish leaders used the vineyard to their own benefit and not to God's advantage. They do not wish to interpret the law to the benefit of people, but to their detriment. They do not wish to see how people are healed, but simply whether it is or isn't what the law permits. The law keeps the 'leaders' apart of all 'sinners', it is used to accuse, to destroy others and to protect themselves. God's vineyard is therefore not administered to God's advantage, but for their own benefit.

Finally God sent his Son. He is however killed and cast outside the vineyard (Mk 12: 6-8). These three verses are, in my opinion, the central idea of the parable. In terms of reference the Gospel starts with what is to hand, therefore only at Mark 12: 6. Mark 12: 7 refers to the actions of the Jewish leaders against Jesus throughout the Gospel, including the conflicts with Jesus about the correct interpretation of the law and their plans to kill Jesus. The words 'then the inheritance shall be ours' expresses beautifully how the Jewish leaders acted up to that point: they rule for themselves, and not for God. They wish to save their lives, and therefore they kill Jesus. However Mark 12: 8, in turn, refers to that which is still to take place further ahead in the Gospel, namely the arrest of Jesus, his conviction and crucifixion (Mk 14: 43-15: 41). Schmithals (1986: 523) is also of the opinion that Mark 12: 8 refers to the suffering and death of Jesus. The fact that 'Jesus' is cast from the vineyard, most probably refers to Jesus's crucifixion outside Jerusalem on Golgotha (Mk 15: 21-32; of Gnilka 1979: 147 and Schmithals 1986: $515-518$ in this connection).

In Mark 12: 9 the farmers are put to death which probably refers to the end of 
the Jewish leaders's control of the religious life (the vineyard) which God placed in their trust. It can even be a reference to the fall of the temple (Mk 13: 1-2: cf Pesch 1977: 217 in this regard). The vineyard which is given to others, is a reference to the church as the eschatological people of God which lives in the sphere of his rule' (Kingsbury 1986: 645), which thus refers back to Mark 2: 20 and 4: 29,32, but also points ahead to the confession of the Roman at the cross and certain sections in Mark 13, where it is apparent that the disciples follow Jesus.

Mark 12: 10-11, which is a citation from Psalm 118: 22-23, refers, like Mark 12: 8 to the Jewish leaders who killed Jesus, but also to his resurrection (the stone that became the most important). In my opinion, the stone also suggests something from Mark 13: 1-2, namely the temple, as a symbol of the Jewish religion and the law, which will be demolished and where the new stone, Jesus, will be the corner-stone of the new vineyard.

The functional role of the position of the parable in terms of the understanding of the Jewish leaders of the identity of Jesus after the telling of the parable, becomes clear as a result of the references in Mark 12: 12. It is clear that the Jewish leaders realise that Jesus is alluding to them as the owners of the vineyard who put the Son to death. They are therefore aware of the fact that Jesus knows of their plans. They also know who Jesus is. He said himself that he is God's Son. This realization of the Jewish leaders causes that the plans which they had made up to that point will now finally be executed, especially because they now have the evidence to find Jesus guilty, namely on the grounds of blasphemy (see Mark 12: 6; 14: 61). The pericope therefore guides the Gospel forcibly ahead towards the end. The three pericopes which directly follow Mark 12: 1-12, serve as a good example of this. Directly after Mark 12: 12 Jesus is questioned by the Pharisees about the payment of taxes (Mk 12: 13-17) and about the most important commandment (Mk 12: 28-34). Here, also the Sadducees question Jesus about the rising from the dead (Mk 12: 18-27). Above it was shown that the pericope follows the question of Jesus's authority. The last mentioned three pericopes treat the question of Jesus' authority. As the telling of the parable of the farmers and the vineyard therefore has its direct result in the question of the Pharisees about Jesus' authority, the parable is likewise followed by further questions to test Jesus's authority. I am of the opinion that this is telling proof of how this pericope guides the plot vigorously to its culmination.

As far as what the disciples' understanding of the identity of Jesus is, after the telling of the parable, it is here again made known to them that Jesus is the Son of God (cf Mk 9: 7) and that he will die as a result of the efforts of the Jewish leaders (Mk 8: 31; 9: 31; 10: 32-33). They however also learn that Jesus will rise from the dead and that his church will survive. They are therefore encouraged anew to keep 
following Jesus as the Son of God, the one who must suffer and die.

The position of Mark 12: 1-12 in terms of the plot of the Gospel can therefore briefly be summarised as follows:

Mark 12: 1-12 does not only sum up everything that happened up to and including Mark 12, but guides the plot to its culmination. That to which the pericope refers in retrospect and in the future, functions in support of the fact that the pericope is anticipatory to the fact that Jesus suffers and dies at the end of the narrative, and in so doing establishes God's new kingdom which is already announced in Mark 1: 1-15.

More important is the fact that Mark 12:1-12 is largely the plot of the Gospel in a nutshell. When we compare the facts which the pericope provides with the formulation of the plot of the Gospel of Mark, as we formulated it at the end of Section 3, the last mentioned point of view becomes clear. Jesus, as the Son of God, is sent by God to the vineyard to make it new. The farmers, who are currently in charge of it, and who are mismanaging it, however, put him to death in order to maintain the status quo. Because they do not understand who this Son really is, they, in turn, are cast from the vineyard and their places are taken by those who are prepared to believe in this Son and to follow him, even though it would mean that they will suffer and die as he did (see also Pesch 1977: 221 in this connection). Who so ever wishes to retain his life, will lose it (the Jewish leaders) and whoever is prepared to lose his life (those who follow Jesus in the post-Easter church) will retain theirs. The new kingdom of God has therefore arrived.

It is therefore clear that the content of the plot, as we defined it at the end of Section 3, is in accord with the content (and also with the plot) of Mark 12: 1-12. For this reason we are also able to state that Mark 12: 1-12 is the plot of the Gospel of Mark in a nutshell.

\section{CONCLUSION}

The above study attempted to read Mark 12: 1-12 in terms of the plot of the Gospel of Mark. After a methodological justification of how the study of the plot should be approached, the plot of Mark is studied in terms of time, characters and the role of the reader. The causal connection between the incidents and the interrelations mentioned above, appeared in the narrative in this manner. At the end of this study (Section 3) there is a formulation of the plot in Mark.

The study of Mark 12: 1-12 in terms of the plot of the Gospel has indicated that this pericope not only plays an important part in the plot which drives the plot forward vigorously to its culmination, but that the pericope in fact summarizes the 
plot of the Gospel in a nutshell.

The viewpoint of Breytenbach (1984: 75-80), namely that the plot of Mark is only episodic, is in my opinion, by this proved to be incorrect. In an episodic plot the incidents follow one another as in a simple story, and the incidents are not arranged in terms of futurity, retrospection, causality and necessity (Matera 1987: 240). Perhaps the reason for this point of view of Breytenbach is the fact that he regards the plot simply as the sum total of the incidents in the beginning, the middle and the ending of the plot.

Van Aarde [1989] is, however, of the opinion that only when it can be indicated how all the incidents in a narrative can be placed in relation to each other, and how they function together in order to produce a communicative effect, can we speak of the plot of a narrative. As a result of the findings of our study which are contrary to those of Breytenbach, the value of Van Aarde's viewpoint are proved.

The plot of Mark permeates causality and relations which are laid between different incidents, and the disguised sequence of time (see Brink 1987: 96) plays a major role in the constitution of the plot of the Gospel (cf also Vorster 1980: 154). The plot is therefore not merely the sum of the total of the incidents in the Gospel. To fail to appreciate the nature of the plot of the Gospel of Mark, is therefore to misread the message as well as the theology of this Gospel.

\section{Works cited}

ABRAMS, MH 1971. A glossary of literary terms. 3rd edition. New York: Holt.

THE POETICS OF ARISTOTLE 1911. Londen: Macmillan.

BOOTH, WC 1961. The rethoric of fiction. Chigaco: Chicago University Press.

BOWEN, E 1960. Notes on writing a novel, in Miller JE (ed), Myth and method. Lincoln: NEB.

BREYTENBACH, C 1984. Nachfolge und Zukunftserwartung nach Marcus: Eine methodenkritische Studie. Zurich: Theologischer Verlag. (ATANT 71.)

BRINK, AP 1987. Vertelkunde: 'n Inleiding tot die lees van verhalende tekste. Pretoria: Academica.

BROOKS, P 1984. Reading for the plot: Design and intention in narrative. Oxford: Clarendon Press.

CRANE, RS 1967. The concept of plot, in Stevick 1967: 141-145.

CULPEPPER, RA 1983. Anatomy of the Fourth Gospel: A study in literary design. Philadelphia: Fortress Press.

DIPPLE, E 1970. Plot, in Dump JJ (ed), The critical idiom. London: Methuen.

DONAHUE, JR 1982. Jesus as the parable of God in the Gospel of Mark. JBL 
$104 / 2,77-92$.

EGAN, K 1978. What is a plot? New Literary History, $454-73$.

FORD, FM 1959. Joseph Conrad: A personal remembrance, in Allott M (ed), Novelists and the novel. New York: Columbia University Press.

FORSTER, EM 1927. Aspects of the novel. London: Edward Arnold.

FORSTER, EM 1961. The plot, in Scholes R (ed), Approaches to the novel: Materials for poetics, 219-232. San Francisco: Chandler Publishing Company.

FRIEDMAN, N 1967. Forms of the plot, in Stevick 1967: 145-165.

GENETTE, G 1980. Narrative discourse. Oxford: Blackwell.

GNILKA, J 1978. Das Evangelium nach Markaus, II/l. Zurich: Neukirchener Verlag. (EKK.)

GNILKA, J 1979. Das Evangelium nach Markus, II/2. Zurich: Neukirchener Verlag. (EKK.)

GOODMAN, P 1954. The structure of literature. Chicago: Chicago University Press.

GRäBE, I 1986. Die gelykenis van die barmhartige Samaritaan: Narratiewe tegnieke en vergelykingskonstruksies. $H T S 42 / 2,265-281$.

KECK, LE 1966. The introduction to Mark's Gospel. London: Oxford.

KENNEY, W 1966. How to analyse fiction. New York: Monarch.

KERMODE, F 1979. The sense of an ending: Studies in the theory of fiction. London: Oxford University Press.

KINGSBURY, JD 1986. The parable of the wicked husbandmen and the secret of Jesus' divine sonship in Matthew: Some literary-critical observations. JBL 105/4, 643-655.

LäMMERT, E 1972. Bauformen des Erzählens. 5. Aufl. Stuttgart: Metzlersche Verlagsbuchhandlung.

LEMCIO, EE 1986. The intention of the evangelist Mark. NTS 32, 187-206.

LUZ, U 1965. Das geheimnismotiv und die Markanische Christologie. ZNW 56, 930.

MATERA, FJ 1987a. The plot of Matthew's Gospel. CBQ 49, 233-253.

MATERA, FJ 1987b. What are they saying about Mark? Mahwah: Paulist Press.

MATERA, FJ 1988. The prologue as the interpretative key to Mark's Gospel. JSNT 34, 3-20.

MARTIN, RP 1972. Evangelist and theologian. Münchin: Exeter.

MUIR, E 1968. Novels of action and character. London: SCM Press.

PESCH, R 1977. Das Markusevangelium, II. Teil. Freiburg: Herder (HThK 2.)

PELSER, GMM 1983. Die aktante-model van AJ Greimas, in Van Aarde AG (red), 35-57. Interpretasiemodelle in Evangelienavorsing. Pretoria: Departement Nuwe-Testamentiese Wetenskap (Afdeling A), Universiteit van Pretoria. 
PERRIN, N 1974. The New testament: An introduction. Proclamation and paranesis, myth and history. Chicago: Chicago University Press.

PETERSEN, NR 1980. When is the end not the end? Literary reflections on the ending of Mark's narrative. Interp. 34, 151-66.

PETERSEN, NR 1980. The composition of Mark 4: 1-8: 26. HThR 73, 185-217.

RäISäNEN, H 1976. Das 'Messiasgeheimnis' im Markusevangelium. Helsinki: LänsiSuomi. (Schriften der Finnischen Exegetischen Gesellschaft 28.)

RHOADS, D \& MICHIE D 1982. Mark as story: An introduction to the narrative of a Gospel. Philadelphia: Fortress.

RHOADS, D 1983. Narrative criticism and the Gospel of Mark. JAAR 50, 411-434.

RICOEUR, P 1980. Narrative time, in Mitchell WJT (ed), On narrative. Chicago: Chicago University Press.

RIMMON-KENAN, S 1983. Narrative fiction: Contemporary poetics. London: Methuen.

SCHMITHALS, W 1986. Das Evangelium nach Markus. Kapitel 9,2 - 16,20. 2. Aufl. Würzburg: Gütersloher Verlaghaus. (Oekumenischer TaschenbachKommentar zum Neuen Testament 2/2.)

SCHOLES RE \& KELLOGG R 1966. The nature of narrative. New York: Oxford University Press.

SCHOLES, R 1974. Structuralism in literature: An introduction. New Haven: Yale University Press.

SENEKAL, J 1985. Handelingsverloop, in Cloete TT et al (reds), Gids by die literatuurstudie. Pretoria: HAUM-Literêr

STEVICK, P (ed) 1967. The theory of the novel. New York: The Free Press.

TANNEHILL, RC 1980. The Gospel of Mark as narrative christology. Semeiea 16, 57-95.

TANNEHILL, RC 1983. The disciples in Mark: The function of a narrative role. JR 75, 386-405.

TOMAHEVSKY, B 1965. Thematics, in Lemon LT \& Reis MJ (eds), Russian Formalist Criticism. Lincoln: NEB.

VAN AARDE, AG [1989]. Narrative criticism aplied to Jn 4: 43-54, in Hartin, PJ \& Petzer, JH (eds), Text and interpretation: New approaches in the criticism of the New Testament. Leiden: Brill. (Forthcoming)

VAN AARDE, AG 1983. Interpretasiemodelle in Evangelienavorsing. Pretoria: Departement Nuwe-Testamentiese Wetenskap (Afdeling A), Universiteit van Pretoria. 
VAN AARDE, AG 1986. Plot as mediated through point of view, in Petzer JH \& Hartin, PJ (eds), A South African perspective on the New Testament, 62-75. Leiden: Brill.

VANDERMOERE, H 1976. The study of the novel. A structural approach. Leuven: Acco.

VAN ECK, E 1984. Galilea en Jerusalem in die Markusevangelie. 'n Literatuurteoretiese evaluering van die bydrae van W Marxsen. BD-skripsie, Universiteit van Pretoria.

VAN ECK, E 1986. Die funksie van ruimte in die narratologie. HTS 42/2, 139-149.

VAN ECK, E 1988. Galilea en Jerusalem as narratologiese ruimtes in die Markusevangelie: 'n Kontinuering van die Lohmeyer-Lightfoot-Marxsen ketting. HTS 44, 139-163.

VORSTER, WS 1980. Die Evangelie volgens Markus: Inleiding en teologie, in Du Toit AB (red), Handleiding by die Nuwe Testament, IV. Die Sinoptiese Evangelies en Handelinge: Inleiding en teologie, 109-155. Pretoria: NG Kerkboekhandel.

VORSTER, WS 1985. Meaning and reference: The parables of Jesus in Mark 4, in Lategan, BC \& Vorster WS (eds), Text and reality: Aspects of reference in biblical texts, 27-66. Philadelphia: Fortress Press.

VORSTER, WS 1987a. Characterization of Peter in the Gospel of Mark. Neotestamentica, 21/1, 57-76.

VORSTER, WS 1987b. Literary reflections on Mark 13: 3-37: A narrated speech of Jesus. Neotestamentica, 21/2, 203-222.

WEEDEN, TJ 1968. The heresy that necessitated Mark's Gospel. ZNW 59, 145 158.

WEEDEN, TJ 1971. Mark: Traditions in conflict. Philadelphia: Fortress Press.

WREDE W 1969. Das Messiasgeheimnis in den Evangelien. Zugleich ein Beitrag zum Verständnis des Markusevangeliums. 4. Aufl. Göttingen: Ruprecht. 